\title{
Marek Szajda
}

[Ośrodek „Pamięć i Przyszłość”]

(D) https://orcid.org/0000-0002-1938-6762

Sprawozdanie z X spotkania warsztatowego Polskiego Towarzystwa Historii Mówionej

DOI: $10.26774 / \mathrm{wrhm} .311$ 
Polskie Towarzystwo Historii Mówionej od początku swojej działalności organizuje spotkania warsztatowe skierowane do członków organizacji oraz wszystkich zainteresowanych historią mówioną. Tegoroczne wydarzenie było jubileuszowym, bo dziesiątym, i jednocześnie pierwszym spotkaniem po wielomiesięcznej przerwie spowodowanej rozprzestrzenianiem się wirusa sARs-CoV-2. Odbyło się ono 23 października 2021 r. w Warszawie. Poprzednie spotkanie Ртнм-u zorganizowano w formie zdalnej jesienią 2020 r. ${ }^{1}$ Jednym z jego efektów były rekomendacje Towarzystwa dot. praktykowania historii mówionej w trakcie epidemii Covid-19².

Tym razem miejscem spotkania był Wydział Historii Uniwersytetu Warszawskiego, a tematami obrad kwestie: interpretacji relacji oraz ochrony danych osobowych w oral history w Polsce. W dyskusji panelowej poświęconej pierwszemu problemowi udział wzięli badacze i badaczki z różnych dyscyplin naukowych oraz ośrodków badawczych. Wśród nich znaleźli się: dr hab. Kaja Kaźmierska, prof. uŁ (Instytut Socjologii Uniwersytetu Łódzkiego), dr Ewa Kępa (Instytut Studiów Kulturowych Uniwersytetu w Białymstoku), dr Andrzej Czyżewski (Instytut Historii Uniwersytetu Łódzkiego) oraz Damian Gocół (Instytut Filologii Polskiej Uniwersytetu Marii Curie-Skłodowskiej w Lublinie). Dyskusję prowadził dr Marcin Jarząbek, prezes Polskiego Towarzystwa Historii Mówionej (Instytut Historii Uniwersytetu Jagiellońskiego). Materiałem, który omawiano, analizowano i interpretowano była relacja historii mówionej Haliny Duczmal-Pacowskiej, pochodząca ze zbiorów Ośrodka „Pamięć i Przyszłość” we Wrocławiu, zarejestrowana w ramach projektu „100 100-latków na 100-lecie”3. Uczestnicy debaty, podejmując się interpretacji wywiadu, zwracali uwagę na różne kwestie, m.in. historyczne (brak odniesień do faktografii oraz narracja przedstawiające życie „obok PRL-u”), socjologiczne (niewchodzenie przez rozmówczynię w szczegóły biograficzne, zwłaszcza te dotyczące okresu wojennego), a także kulturowe (specyfika opowieści typowa dla narracji kobiecej czy osoby starszej). Zarówno ograniczeniem, jak i wartością wywiadu jest jego charakterystyka wynikająca z założeń projektu - rozmów z najstarszymi Polakami, tj. urodzonymi

1 Zob.: M. Szajda, Sprawozdanie z webinarium Polskiego Towarzystwa Historii Mówionej z 19 IX 2020 r., „Śląski Kwartalnik Historyczny Sobótka”, R. LXXV (3/2020), s. 174-176.

2 Polskie Towarzystwo Historii Mówionej, Historia mówiona a Epidemia covid-19. Rekomendacje Polskiego Towarzystwa Historii Mówionej: covid-19 and Oral History. Guidelines of the Polish Oral History Association, „Wrocławski Rocznik Historii Mówionej”, R. 10 (2020), s. 246-256.

3 Aopip, sygn. AHM-789, Relacja Haliny Duczmal-Pacowskiej, 17 IV 2018 r. (sporządziła: E. Sowińska); Zob. również: Rówieśnicy Niepodległej. Sto lat historii Polski z perspektywy najstarszych Polaków, red. K. Bock-Matuszyk, E. Maj, A. Paprot-Wielopolska; współpraca red. M. Szajda, P. Zubowski, Wrocław 2020. 
w 1923 r. lub wcześniej. Sam temat, dobór rozmówcy, ale również pytania kwestionariuszowe stworzyły swoistą ramę koncepcyjną, w którą świadek historii wpisał swoją narrację. Ciekawym wątkiem była dyskusja wokół pytania o nadrzędną kategorię, poprzez którą można opisać omawianą relację. Uczestnicy dyskusji zgodzili się, że tą kategorią jest m.in. „doświadczenie”, „osobiste doświadczenie” czy „doświadczenie życiowe”. Innymi, wartymi wspomnienia pojęciami były: „pokoleniowość” oraz „etos” - specyficzny zwłaszcza dla osób starszych, wychowanych jeszcze w okresie II RP, odwołujących się w swoim przekazie do wartości. Dyskusja, w której uczestniczyli również zebrani słuchacze oraz osoby biorące udział za pośrednictwem transmisji internetowej, była niezwykle ciekawa, czego potwierdzeniem są deklaracje organizatorów o kontynuowaniu tego typu debat skupionych na interpretacji wywiadów historii mówionej.

W drugiej części spotkania dr hab. Marek Konstankiewicz, prof. umcs (Instytut Historii Uniwersytetu Marii Curie-Skłodowskiej w Lublinie) przybliżył zebranym akty prawne obowiązujące w Polsce, a dotyczące RoDo, ze szczególnym uwzględnieniem badań dot. historii mówionej. Swój wykład oparł na analizie obowiązujących regulacji, m.in. rozporządzenia Parlamentu Europejskiego oraz ustawy z dnia 10 maja 2018 r. o ochronie danych osobowych. Słuchacze dowiedzieli się o zakresie ochrony i przetwarzania danych osobowych, obowiązkach osób administrujących danymi, a także o szczególnych zasadach przetwarzania danych osobowych, w tym na potrzeby pracy akademickiej. Istotnym kontekstem, ważnym dla badaczy oralistów, jest również ustawa z dnia 20 lipca $2018 \mathrm{r}$. - Prawo o szkolnictwie wyższym i nauce. Wykład ten w sposób niezwykle szczegółowy porządkował informacje na temat możliwości przetwarzania danych osobowych, z pewnością poszerzając zakres dotychczasowej wiedzy wśród słuchaczy. Jednocześnie warto dodać, iż zależnie od celów wykorzystania relacji, pracy badawczej oraz afiliacji instytucjonalnej, można różnie interpretować zapisy odnoszące się do RODo w historii mówionej. Dobrym tego przykładem są wyłączenia dot. badań naukowych, właściwe dla akademików, ale już nie dla pracowników instytucji kultury.

Na zakończenie wydarzenia nastąpiły krótkie ogłoszenia organizatorów na temat bieżących prac Towarzystwa oraz planów na najbliższą przyszłość, w tym organizacji walnego zgromadzenia członków w 2022 r. oraz wsparcia dla badaczy historii mówionej na Białorusi. Zapis obu części spotkania warsztatowego znajduje się na profilu ртнм-u na Facebooku 